\title{
Quantitative Analysis of Collagen Fibrillar Structure in Canine Uterus Exposed to Acetate of Medroxyprogesterone Using Second Harmonic Generation Microscopy
}

\author{
Análisis Cuantitativo de la Estructura de Fibras Colágenas en Útero Canino Expuesto a Acetato \\ de Medroxiprogesterona Utilizando Generación Microscópica de un Segundo Harmónico
}

Paulo Salinas'; Maria Angélica Miglino² \& Mariano del Sol ${ }^{3,4}$

SALINAS, P.; MIGLINO, M. A. \& DEL SOL, M. Quantitative analysis of collagen fibrillar structure in canine uterus exposed to acetate of medroxyprogesterone using second harmonic generation microscopy. Int. J. Morphol. 35(1):157-161, 2017.

SUMMARY: Collagen is the most abundant structural protein found in organs and is responsible for providing tissues with structure and function. In order to investigate in canine uteri the potential effect of medroxyprogesterone acetate (MPA) on the changes in collagen deposition were grouped as nulliparous $(n=11)$, multiparous $(n=11)$ and treated with MPA ( $n=11$; nulliparous with two treatments; $5 \mathrm{mg} / \mathrm{kg}$; i.m.). The amount of collagen was studied in the fold and basal regions of the endometrium and myometrium using second harmonic generation with a two-photon spectral confocal microscope, quantified using ImageJ software with a color segmentation plugin, was expressed as fraction area $(\%)$ and analyzed by ANOVA $(\mathrm{p}<0,05)$. No differences were observed between groups in the fold $(p=0,3995)$ or base $(p=0,7392)$ of the endometrium and myometrium $(p=0,1781)$. In conclusion, our data demonstrate that two doses of MPA (5 mg/kg; i.m.) do not affect the total collagen deposition in canine uteri undergoing contraceptive treatment.

KEY WORDS: canine, medroxyprogesterone acetate, collagen, second harmonic generation.

\section{INTRODUCTION}

Medroxyprogesterone Acetate (MPA) is one of the main contraceptive progestins used to control the world's canine population and with megestrol acetate, proligestone and gonadotropin-releasing hormon, these are the most frequently used drugs for nonsurgical contraception in bitches and cats. The study of the medium-term effect of MPA on collagen synthesis and distribution in the uterus can aid in understanding the underlying and causal microscopic changes in which collagen plays an important role, such as those that occur during decidualization, implantation, pregnancy and uterine involution. Yet despite the usefulness of its therapeutic effects, numerous side effects have been described (Monteiro et al. 2009). Reports indicate that the clinical and/or endocrinal effect on the reproductive system varies according to the dose and time of application with respect to the estrous cycle. Studies describe the effect of progestins on collagen synthesis. One of the mechanisms involved is the inhibitory property that progestins have on the expression of extracellular matrix metalloproteinases (MMP), which regulate the deposition of collagen in the tissue degrading it (Oner et al., 2008).

Collagen is the most important and abundant extracellular protein present in animal tissue. It is located mainly in bone, cartilage, skin, interstitial space and basal lamina and is responsible for giving tissues strength, structure and function. Every collagen molecule is nonsymmetrical and is arranged in a triple helix, with several shapes being described. Minor modifications in the amino acids that comprise the molecule affect its final make-up and, therefore, give different functions to the different types of collagen in the living organism. Collagen molecules organize naturally into structures called fibers on the scale of the wavelength of light and lack inversion symmetry, thus allowing for the process of second harmonic generation (SHG) when exposed to intense incident light [HML1] [PS2] (Rao et al., 2009).

\footnotetext{
${ }^{1}$ Institute of Biology, Faculty of Sciences, Pontificia Universidad Católica de Valparaíso, Chile.

${ }^{2}$ Department of Surgery, Faculty of Veterinary Medicine and Animal Science, University of São Paulo, Brazil.

${ }^{3}$ Center of Excellence in Morphological and Surgical Studies (CEMyQ), Faculty of Medicine, Universidad de La Frontera, Chile.

${ }^{4}$ Center of Biomedical Research, Universidad Autónoma de Chile.
} 
Due to its underlying physical origin, it is highly sensitive to the 3D make-up of collagen fiber (Chen et al., 2012). The first ruby laser was made by Thedore Maiman in the 1960s, which produced pulses of deep red light within the human visible range $(697 \mathrm{~nm}$; Rao et al., 2009). It was later discovered that the bright pulses of the ruby laser light that passed through a quartz crystal produced light near the ultraviolet level (348 nm; Franken et al., 1961). Therefore, the SHG occurs when the electric field of the excitation light is sufficiently powerful to modify the 3D make-up of a molecule. If this is not symmetrical, the resulting anisotropy creates an oscillating field twice the original frequency, which was called SHG (Gauderon et al., 2001). Therefore, the capacity to generate harmonic seconds is inherent to the molecules that are not center-symmetrical, such as fibrillar collagen (Campagnola et al., 2002). Consequently, Rao et al. (2009) described that SHG microscopy has become a powerful tool used frequently in biomedicine to obtain high contrast 3D images of collagen fibers without requiring histological staining and in a wide tissue range, th[HML3] erefore, quantification of the organization of collagen on cellular and molecular scales has been described as crucial to understanding the structure and function, evaluating the health of the tissue and identifying specific damage early, and even the changes that occur in diseases such as cancer, fibrosis and connective tissue disorders (Chen et al., 2012).

We hypothesize that the progestin MPA exerts a likely inhibitory effect on the expression of metalloproteinases in the uterine tissue when it is used as a contraceptive. The aim of this study was to describe the effect and compare the amount of collagen present in different uterine layers in dogs subjected to contraceptive treatment with MPA and those who were exposed only to physiological concentrations of progesterone.

\section{MATERIAL AND METHOD}

Ethics Statement. This study was conducted at the Center for Excellence in Surgical and Morphological Studies of the Universidad de La Frontera, Temuco, Chile. The animals were handled in accordance with guidelines for animal research as detailed in the NIH Guidelines for the Care and Use of Laboratory Animals (NIH, 1985) with ethical approval from the Universidad Santo Tomás Research Ethics Committee CE 081/2013.

Animals, samples and determination of estrous cycle. Complete uteri were obtained from 33 healthy adult female dogs (Canis lupus familiaris) from the University's Animal
Hospital, with no defined breed, subjected to ovariohysterectomy during anestrus (18 months - 6 years). Uteri were classified as nulliparous $(n=11$; older than 9 months, that had experienced at least one estrous cycle), multiparous ( $\mathrm{n}=11$; older than 9 months, that had experienced at least two full-term gestations and involution of the uterus after the last gestation was complete) and MPA-treated bitches ( $\mathrm{n}=11$; nulliparous exposed twice to contraceptive treatment during late anestrus). Treatment with a synthetic progestin depot preparation of MPA (OVO- $6{ }^{\circledR} 50 \mathrm{mg}$, Drag Pharma Laboratory Invetec S.A., Chile) was begun during anestrus giving two treatments of $5 \mathrm{mg} / \mathrm{kg}$ i.m. body weight at 8-week intervals. Three days before the start of the treatment with MPA the stage of the estrous cycle was assessed. Anestrus was confirmed using physical examination, vaginal cytology (Concannon, 2011) (Diff Quick ${ }^{\circledR}$, Hartman Leddon Co, Philadelphia, PA), histological parameters of the uterus and ovaries (Rehm et al., 2007) and confirmed by the absence of the corpus luteum in the ovary. In terms of uterus histological parameters, bitches in anestrus had simple low columnar or cuboidal epithelium, superficial stroma rich in cells, and the stroma of the deeper part of endometrium with less convoluted basal glands with simple cuboidal and in some cases columnar epithelium.

Preparation of the uterine tissue and confocal microscopy. Sections of uterine horn were obtained and fixed in $4 \%$ formaldehyde $\mathrm{v} / \mathrm{v}$ for $72 \mathrm{~h}$ at room temperature. Uterine tissue was cut into $5 \mathrm{~mm}$ thick sections. Multi-images were obtained by LSM780 NLO (Zeiss) two-photon spectral confocal microscope. Second harmonic generation (SHG) microscopy was used to observe collagen fibrillar structure (Chen et al., 2012). The multiphoton microscopy system made it possible to generate deep and three-dimensional images of tissue up to approximately $0.5 \mathrm{~mm}$ in thickness with subcellular resolution. The device has a multiphoton pulsed laser adjustable from 680 to $1080 \mathrm{~nm}$ in increments of $1 \mathrm{~nm}$ and uses low-energy photons (infrared) in extremely short pulses, which reduces the damage caused to the biological samples by the beam from the conventional lasers.

Quantification of collagen. After images around the endometrium and myometrium were obtained, the fraction area (\%) of collagen in the endometrium (apical and basal regions) and myometrium were quantified using Image J software (National Institute of Health) and the "threshold" function and "color segmentation" plugin was used (EPFL, Lausanne, Switzerland) and was expressed as a fraction area (\%) of each image (Schindelin, 2015). This ImageJ plugin allows a color image or a stack of colors to be segmented by pixel clustering. For the quantification of collagen, 10 fields were obtained per section using 40x magnification, and at least three sections for each region per animal were counted. 
Statistical analysis. Data represent the mean of fraction area \pm SD. The D'Agostino-Pearson test was used to evaluate data normality. Statistical comparisons between three groups of data were carried out using an analysis of variance (ANOVA) among the three groups and Tukey's post-test of multiple comparisons was used. Statistical significance for all hypothesis tests was set at $\mathrm{p}<0.05$. The data analysis was performed using GraphPad Prism 5.0 software for Mac OS X (GraphPad Software, San Diego CA).

\section{RESULTS}

In the three analyzed groups, the second harmonic generation by two photons revealed that the endometrium and myometrium had collagen fibers. There was no evidence[HML4] of significant differences in the amount of collagen (fraction area) present in the fold $(\mathrm{p}=0.3995)$ and base of the endometrium ( $\mathrm{p}=0.7392)$ and myometrium $(\mathrm{p}=0.1781$ ) between the study groups (Fig. 2). In the endometrial fold collagen fibers were observed to be organized and arranged in parallel row in the direction of the luminal epithelium. By contrast, this organization was not observed in the uteri exposed to MPA; rather, these were parallel to the luminal epithelium. Collagen fibers were observed at the base of the endometrium surrounding the endometrial glands located near the basal membrane, forming parallel rows in opposite directions, creating a support network. In the myometrium, collagen fibers were observed to be in the same direction as the muscle fibers in the submucosal and supravascular muscle layers. A greater intensity was observed in the multiparous group (Fig.1).

\section{DISCUSSION}

We have shown that two doses of MPA $(5 \mathrm{mg} / \mathrm{kg})$ administered at an 8-week interval does not influence the synthesis or degradation of the total collagen in the canine uterus. Our results do not agree with those reported by Oner et al. (2004), who attribute an inhibitory effect of the MPA on MMP, which control collagen synthesis in the tissue, an assertion that supports our hypothesis. The evidence obtained
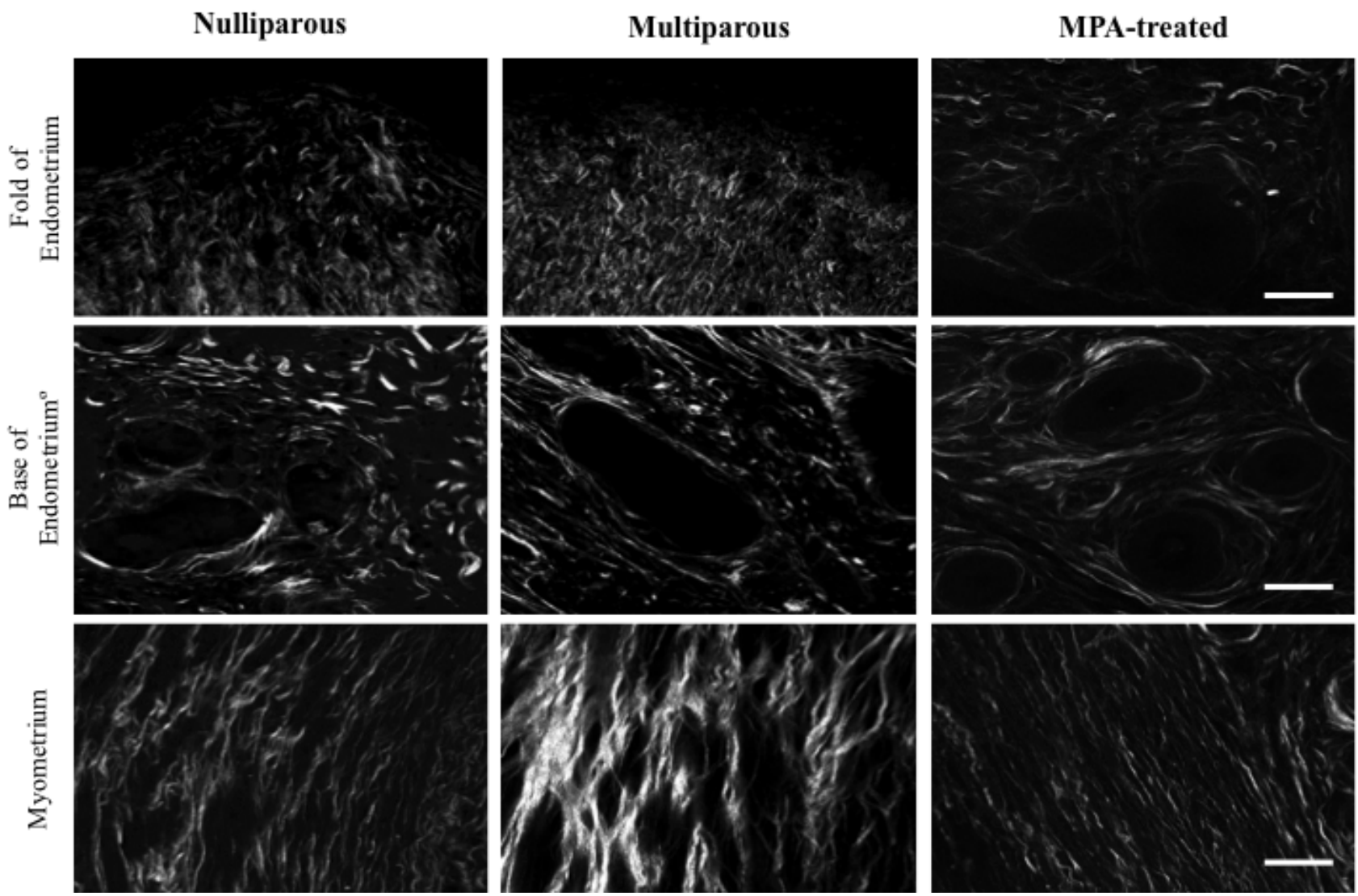

Fig. 1. Interface of SHG images of self-assembled collagen using two-photons. The resulting respective threshold shows a distribution of fiber alignment and intensity. 40X; Scale bar: $20 \mu \mathrm{m}$. 


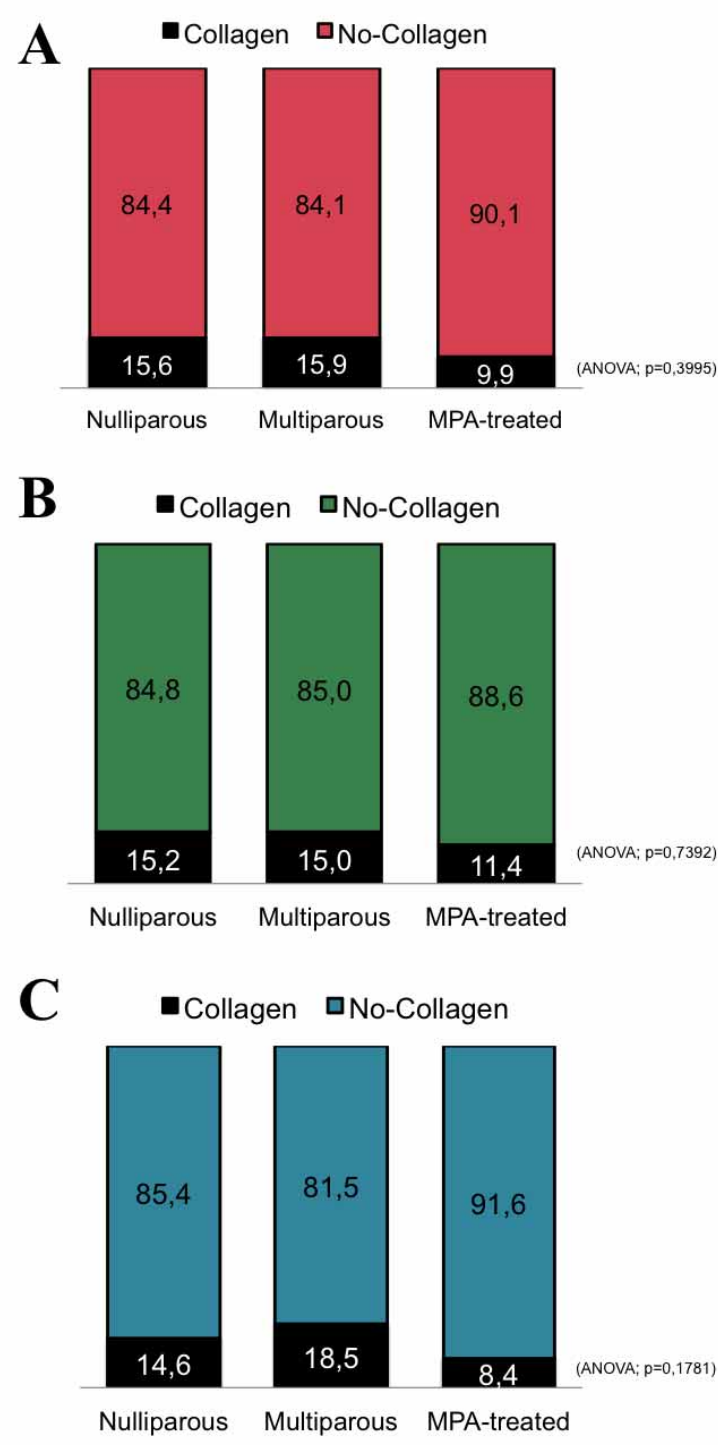

Fig. 2. Fraction area (\%) of total collagen tissue in canine uteri. A) fold and $\mathrm{B}$ ) base of the endometrium and $\mathrm{C})$ myometrium $(\mathrm{n}=11)$.

in this study makes it possible to infer that the dose and dosage used did not produce the indicated inhibitory effect. It is worth noting that this effect has been attributed to the inhibition of collagen degradation induced by interleukin$1 \mathrm{~b}$ depending on the concentration and exposure time (Zhou et al., 2012). As a result, it is possible to suggest that MPA may inhibit the expression of collagenases in the uterus and modulate ECM proteins at therapeutic concentrations greater than $5 \mathrm{mg} / \mathrm{Kg}$; therefore, their biomechanical properties would not be different from those observed in uteri exposed to luteal progesterone in conditions of nulliparity and multiparity.
Progesterone inhibits the expression of MMP in endometrial cells in humans and rats (Marbaix et al., 1992; Hampton et al., 1999). Our results suggest the inhibitory effect described for the exogenous progestin MPA depends on the dose and dosage. The evidence also suggests that in females with normal cycles and under the influence of estrogen, the cells of the smooth muscle can synthesize collagen; however, under certain conditions an increase in the amount of collagen can occur, particularly of Types I and III, which indicates the occurrence of modifications in the biochemical properties of the cells as a response to progesterone (Ross \& Klebanoff, 1971; Stewart et al., 1995). These modifications may be associated with the presence of exogenous progesterone. Shynlova et al. (2004) described the role progesterone plays in collagen expression and synthesis. They demonstrated that non-pregnant uteri had a low capacity to express extracellular matrix protein genes, which shows the limited properties of the uterus to synthesize collagen during the absence of a fetus and consequently during the absence of luteal progesterone. It has also been attributed to a control of collagenolysis during early or delayed pregnancy. In our study, the uterus exposed to two $5 \mathrm{mg} / \mathrm{kg}$ doses of MPA did not exhibit any dramatic changes in the collagen deposition in any of the layers studied compared to those exposed to luteal progesterone in physiological conditions of nulliparity and multiparity, demonstrating that, even when the MPA is a synthetic molecule, it does not interfere with collagen synthesis or expression. This suggests the poor capacity of MPA to attenuate gene transcription at some level at a dose of $5 \mathrm{mg} / \mathrm{Kg}$, without altering collagenolysis, exerting few of the typical anticollagen properties of physiological progesterone (Halme \& Woessner, 1975).

In conclusion, our data demonstrate that two doses of MPA $(5 \mathrm{mg} / \mathrm{kg}$; i.m.) do not affect the total collagen deposition in canine uteri subjected to contraceptive treatment.

\section{ACKNOWLEDGEMENTS}

This research was supported by Programa Formación de Capital Humano Avanzado, Beca Doctorado Nacional, CONICYT (Grant D-21140825).

SALINAS, P.; MIGLINO, M. A. \& DEL SOL, M. Análisis cuantitativo de la estructura de fibras colágenas en útero canino expuesto a acetato de medroxiprogesterona utilizando generación microscópica de un segundo harmónico. Int. J. Morphol. 35(1):157161, 2017.

RESUMEN: El colágeno es la proteína estructural más abundante presente en órganos y es responsable de proporcionar la 
sostén y función a los tejidos. Para investigar en caninos el efecto potencial del acetato de medroxiprogesterona (MPA) sobre cambios en el depósito de colágeno en útero, éstos fueron agrupados como nulíparos $(\mathrm{n}=11)$, multíparos $(\mathrm{n}=11)$ y tratados con MPA ( $\mathrm{n}=11$, nulíparos con dos tratamientos $5 \mathrm{mg} / \mathrm{kg}$, im). El colágeno fue evaluado en el pliegue y regiones basales del endometrio y en miometrio utilizando la Generación de un Segundo Harmónico con un microscopio confocal espectral y dos fotones y cuantificado utilizando el software ImageJ a partir de la segmentación de colores. Los resultados fueron expresados y analizados como fracción de área (\%; ANOVA; $p<0,05)$. No se observaron diferencias entre los grupos en el pliegue $(p=0,3995)$ y base $(p=0,7392)$ del endometrio y tampoco en miometrio $(\mathrm{p}=0,1781)$. En conclusión, nuestra evidencia demuestra que dos dosis de MPA ( $5 \mathrm{mg} / \mathrm{kg}$, i.m.) no afectan el depósito total de colágeno en úteros caninos expuestos a tratamiento anticonceptivo.

PALABRAS Clave: Canino; Acetato de medroxiprogesterona; Colágeno; Segunda generación de armónicos.

\section{REFERENCES}

Chen, X.; Nadiarynkh, O.; Plotnikov, S. \& Campagnola, P. J. Second harmonic generation microscopy for quantitative analysis of collagen fibrillar structure. Nature protocols., 7(4):654-69, 2012.

Campagnola, P. J.; Millard, A. C.; Terasaki, M.; Hoppe P. E.; Malone, C. J. $\&$ Mohler, W. A. Three-dimensional high-resolution second-harmonic generation imaging of endoenous structural proteins in biological tissues. Biophys J., 82:493-508, 2002.

Concannon, P. W. Reproductive cycles of the domestic bitch. Animal Reprod. Sci., 124(3-4):200-10, 2011.

Franken, P. A.; Hill, A. E.; Peters, C. W. \& Weinreich, G. Generation of optical harmonics. Phys. Rev. Lett., 7:118-9, 1961.

Gauderon, R.; Lukins, P. B. \& Sheppard, C. J. R. Simultaneous multichannel nonlinear imaging: combined two-photon excited fluorescence and second harmonic generation microscopy. Micron, 32:685-9, 2001.

Hampton, A. L.; Nie, G. \& Salamonsen, L. A. Progesterone analogues similarly modulate endometrial matrix metalloproteinase- 1 and matrix metalloproteinase- 3 and their inhibitor in a model for long-term contraceptive effects. Mol. Hum. Reprod., 5:365-71, 1999.

Halme, J. \& Woessner, J. F. Effect of progesterone on collagen break- down and tissue collagenolytic activity in the involuting rat uterus. $J$. Endocrinol., 66:357-62, 1975.

Harkness, B. M. L. R. \& Harkness, R. D. The distribution of the growth of collagen in the uterus of the pregnant rat. J. Physiol., 132(3):492-501, 1956.

Oner, C.; Schatz, F.; Kizilay, G.; Murk, W.; Buchwalder, L. F.; Kayisli, U. A.; Arici, A. \& Lockwood, C. J. Progestin-inflammatory cytokine interactions affect matrix metalloproteinase- 1 and -3 expression in term decidual cells: implications for treatment of chorioamnionitis-induced preterm delivery. J. Clin. Endocrinol. Metab., 93(1):252-9, 2008.

Marbaix, E.; Donnez, J.; Courtoy, P. J. \& Eeckhout, Y. Progesterone regulates the activity of collagenase and related gelatinases A and B in human endometrial explants. Proc. Natl. Acad. Sci. USA., 89:11789-93, 1992.

Rao, R. A. R.; Mehta, M. R.; Leithem, S. \& Toussaint, K. C. Quantitative analysis of forward and backward second-harmonic images of collagen fibers using Fourier transform second-harmonic-generation microscopy. Opt. lett., 34(24):3779-81, 2009.

Rehm, S.; Stanislaus, D. J.; Williams, A. M.; Stanislaus, Ã. D. J. \& Williams, A. M. Estrous cycle-dependent histology and review of sex steroid re- ceptor expression in dog reproductive tissues and mammary gland and associated hormone levels. Birth Defects Res. B. Dev. Reprod. Toxicol., 80(3):233-45, 2007.

Ross, R. \& Klebanoff S. J. The smooth muscle cell. I. In vivo synthesis of connective tissue proteins. J. Cell. Biol., 50:159-71, 1971.

Schindelin J.; Rueden C.T.; Hiner M. C. \& Eliceiri K.W. The ImageJ ecosystem: An open platform for biomedical image analysis. Mol. Reprod. Dev., 82(7-8):518-29, 2015.

Shynlova O.; Mitchell J. A.; Tsampalieros, A.; Langille, B. L. \& Lye, S. J. Progesterone and gravidity differentially regulate expression of extracellular matrix components in the pregnant rat myometrium. Biol. Reprod., 70(4):986-92, 1994.

Stewart, E. A.; Floor, A. E.; Jain, P. \& Nowak, R. A. Increased expression of messenger RNA for collagen type I, collagen type III, and fibronectin in myometrium of pregnancy. Obstet. Gynecol., 86:417-22, 1995.

Zhou, H.; Kimura, K.; Orita, T.; Nishida, T. \& Sonoda, K. H. Inhibition by Medroxyprogesterone Acetate of Interleukin-1b-Induced Collagen Degradation by Corneal Fibroblasts. Invest. Ophthalmol. Vis. Sci., 53(7): 4213-9, 2012.

\author{
Corresponding author: \\ Dr. Mariano del Sol \\ Centro de Excelencia en Ciencias Morfológicas y Quirúrgicas \\ CEMyQ \\ Facultad de Medicina \\ Universidad de La Frontera \\ Temuco \\ CHILE
}

Email: mariano.delsol@ufrontera.cl

Received: 12-09-2016

Accepted: 22-11-2016 